Original Article

\title{
The reliability of the one maximum repetition in sedentary, active and strength-trained subjects
}

\author{
Carlos Leandro Tiggemann \\ Matheus Giacobbo Guedes \\ Roberta Bgeginski \\ Ronei Silveira Pinto \\ Luiz Fernando Martins Kruel
}

\author{
Laboratório de Pesquisa do Exercício, Escola de Educação Física, Universidade Federal \\ do Rio Grande do Sul, Porto Alegre, RS, Brasil
}

\begin{abstract}
The aim of the study was to verify the reliability of one maximum repetition (1-RM) in three different groups, according levels of physical fitness. The sample was composed for thirty subjects (aged 18 to 34 years old) divided in three groups with ten subjects each: sedentary (SG), physical active (PAG) and strength-trained (STG). The subjects were submitted to two familiarization sessions and two sessions of maximum strength test (1-RM1 and 1-RM2) at the following exercises: bench press and $45^{\circ}$ leg press. The comparison between 1-RM values was made by two-way ANOVA (test and group) and association between both by intraclass coefficient correlation $(p \leq 0.05)$. Data presented high correlation values between both tests (from 0.922 to $0.997 ; p<0.001)$, however, significant differences $(p<0.05)$ was observed between 1 RM1 and 1-RM2 at bench press exercise in SG $(56.40 \pm 8.00 \mathrm{~kg}$ e $57.60 \pm 7.89 \mathrm{~kg}$, respectively), PAG $(68,80 \pm 9,26 \mathrm{~kg}$ e $69,40 \pm 8,78 \mathrm{~kg}$, respectively) and STG $(87.20 \pm 19.94 \mathrm{~kg}$ e $88.60 \pm 19.86 \mathrm{~kg}$, respectively), as well in the leg press in $S G(222,5 \pm 38,24 \mathrm{~kg}$ e $229,50 \pm 38,55 \mathrm{~kg}$, respectively), PAG $(238.50 \pm 26.25 \mathrm{~kg}$ e $244.00 \pm 24.70$, respectively) and STG $(321.50 \pm 46.19 \mathrm{~kg}$ e $336.40 \pm 40.44 \mathrm{~kg}$, respectively). It can be concluded that the subject's level of physical fitness does not appear to be a critical behavior at 1-RM reliability.
\end{abstract}

Key Words: Ength training. 1-RM test. Level of physical fitness.

\section{Reprodutibilidade de uma repetição máxima em sujeitos sedentários, ativos e treinados em força}

Resumo: O objetivo deste estudo foi verificar a reprodutibilidade do teste de 1-RM em três diferentes grupos, conforme seu histórico de prática de exercícios. A amostra foi composta por trinta sujeitos (entre 18 e 34 anos): sedentários (GSE, $n=10$ ), fisicamente ativos (GFA, $n=10$ ) e treinados em força ( $G T F, n=10$ ) e foram submetidos a duas sessões de familiarização e a duas sessões de testes de força máxima (1-RM1 e 1-RM2) nos exercícios supino reto e pressão de pernas $45^{\circ}$. Foi utilizado a ANOVA two-way (teste e grupo) e o teste de correlação intra-classe $(p \leq 0,05)$. Verificaram-se altos valores de correlação entre os testes (de 0,922 a 0,$997 ; p \leq 0,001)$, contudo, diferenças significativas $(p \leq 0,05)$ foram encontradas entre 1 RM1 e 1-RM2 no exercício supino para o GSE (56,40 $\pm 8.00 \mathrm{~kg}$ e $57,60 \pm 7,89 \mathrm{~kg}$, respectivamente), GPA $(68,80 \pm 9,26 \mathrm{~kg}$ e $69,40 \pm 8,78 \mathrm{~kg}$, respectivamente) e GTF $(87,20 \pm 19,94 \mathrm{~kg}$ e 88,60 $\pm 19,86 \mathrm{~kg}$, respectivamente), assim como no exercício pressão de pernas para o GSE $(222,5 \pm 38,24 \mathrm{~kg}$ e $229,50 \pm$ $38,55 \mathrm{~kg}$, respectivamente), GPA (238,50 $\pm 26,25 \mathrm{~kg}$ e $244,00 \pm 24,70 \mathrm{~kg}$, respectivamente) e GTF (321,50 $\pm 46,19 \mathrm{~kg}$ e $336,40 \pm 40,44 \mathrm{~kg}$, respectivamente). Logo, pode-se concluir que o perfil do histórico de prática de exercícios dos sujeitos parece não ser um fator decisivo no comportamento da reprodutibilidade dos testes de 1-RM.

Palavras-chave: Treino de força. Teste de 1-RM. Nível de aptidão física.

\section{Introduction}

Strength training (ST) is an important component of physical fitness for both athletic performance and health (ATKINSON e NEVILL, 1998; BAECHLE e GROVES, 2000). While a number of variables constitute ST (sets, repetitions, sessions, velocity and intervals between sets, among others), load is one of the most important (TAN, 1999).
The most widely used method of selecting the load to be used in ST is the one repetition maximum test (1-RM) (HUNTER et al., 2001; KRAEMER et al., 2004), which is the maximal amount of weight that can be lifted in one repetition (BROWN e WEIR, 2001). Once the value of the 1-RM is identified, percentages of that value, based on the training objectives and the population, are applied in the prescription of the ST (RATAMESS et al., 2009). 
Although there is no clearly defined protocol for the application of the 1-RM test, several aspects need to be taken into account to ensure that the real maximum strength value is obtained. Among these aspects, is possible to identify the total number of attempts, the length of the recovery interval and the range of the motion (BROWN e WEIR, 2001). Moreover, other aspects may interfere in the measurement process when repeated evaluations are made on subsequent days, as for example, the subjects' degree of familiarization or training with the evaluated exercise (the learning effect), or the personal motivation of each assessed individual on a certain day (ATKINSON e NEVILL, 1998).

The reliability of the test is an important aspect when measuring a determined variable, as there is an inevitable degree of error associated with the evaluation (ATKINSON e NEVILL, 1998; MORROW et al., 2003). Identifying the real value of maximum strength of the subjects have a fundamental importance for the adequate selection of the loads/intensities to be applied, as well as in the interpretation of the results obtained from a certain training program (PEREIRA e GOMES, 2003). Therefore, the application of successive maximum strength tests has been recommended (PEREIRA e GOMES, 2003; BROWN e WEIR, 2001).

Using association tests, such as Pearson product-moment correlation and intraclass coefficient correlation, several studies (PEREIRA e GOMES, 2003; MCCURDY et al., 2004; TAGESSON e KVIST, 2007) have found high and significant correlations values $(r>0.94)$ in the 1 RM test and retest. However, in this situation, high correlation values only show that similar behavior was found between different responses pairs, and do not necessarily present similar mean values. Similarly, in relation to statistical analysis, some studies using t-test and/or analysis of variance (ANOVA) have found significant differences when examining the results from successive 1-RM tests, with variations of between 12 to $30 \%$ (PLOUTZSNYDER e GIAMIS, 2001; CRONIN e HENDERSON, 2004; GURJÃO et al., 2005). It is also important to note that the range of these variations in test and retest situations are also commonly reported as result of alterations to strength values in detriment to several weeks of ST (
Although several studies have investigated 1$\mathrm{RM}$ test and retest behavior patterns in relation to age (PLOUTZ-SNYDER e GIAMIS, 2001; GURJÃO et al., 2005), sex (CRONIN e HENDERSON, 2004; MCCURDY et al., 2004; PLOUTZ-SNYDER e GIAMIS, 2001), type of exercise (CRONIN e HENDERSON, 2004; TAGESSON e KVIST, 2007), few studies have looked into its behavior in relation to different physical conditions or the training level of the subjects (MCCURDY et al., 2004; RYDWIK et al., 2007; RITTI-DIAS et al., 2011). Rydwik et al. (2007) found strong correlations $(r=0.97 ; p<$ 0.001 ) in groups with and without experience in ST, although, elderly women (up to 75 years old) of both sex were tested in only one exercise (lat pull down), however was not clear in the study what was the involvement level of the subjects in ST. Also in the study from MCCURDY et al. (2004), strength trained and untrained, men and women presented high correlation values between test and retest $(0.97-0.99 ; p<0.05)$, with significant higher values $(p<0.05)$ being found in the second evaluation in all groups. However, in that study, only the unilateral modified squat exercise was tested, with which even the strengthtrained subjects were unfamiliar. In addition, the authors failed to exactly indicate whether the untrained subjects were sedentary or physically active. Ritti-Dias et al. (2011) analyzed the influence of previous experience in ST on the reliability of 1-RM test when performed bench press and squat in four sessions, in distinct days. They have found high correlation values between the four sessions (Bench press: no previous ST experience $r=0.96,24$ months of ST experience $r$ $=0.94$; Squat: no previous ST experience $r=0.94$, 24 months of ST experience $r=0.94$ ).

Therefore, given this gap in the scientific literature, the aim of the present study was to verify the reliability of one maximum repetition (1$\mathrm{RM}$ ), in the bench press and leg press exercises, in three different groups, according to the history of physical fitness - sedentary, physical active and strength-trained.

\section{Participants}

\section{Methods}

Thirty apparently healthy men, aged between 18 and 34 years old, free from any musculoskeletal and/or cardiorespiratory problems, volunteered to participate in this study. Calculation of the sample " $n$ " was carried out 
using the PEPI program (version 4.0) with a power of $90 \%$.

The participants were recruited through an advertisement placed in a widely distributed newspaper of Rio Grande do Sul. Subjects were matched according to training status (last 12 months) into three different groups: the sedentary group ( $\mathrm{SG}, \mathrm{n}=10$ ) was composed of men who were not participating in any form of regular physical exercise; physically active group (PAG, $n$ $=10$ ) was composed of men who regularly exercised (walking, jogging, run, recreational activities; 3-4 times a week) and that had not been involved in ST for at least 12 months from the beginning of this study; strength-trained group (STG, $\mathrm{n}=10$ ) was composed of men who practiced ST regularly for at least 2 years, and that were used to performing sets with load ranges corresponding to 6 - 15 RMs during 3-4 session a week. No significant difference $(p<0.05)$ was found between the three groups for age, body mass, height, sum of skinfold thickness, percent of fat mass and lean body mass (table 1).

Table 1. Physical characteristics of sedentary (SG), physical active (PAG) and strength-trained (STG) groups.

\begin{tabular}{lcccc}
\hline \multicolumn{1}{c}{ Variable } & $\mathbf{S G}(\mathbf{n}=\mathbf{1 0})$ & $\mathbf{P A G}(\mathbf{n}=\mathbf{1 0})$ & $\mathbf{S T G}(\mathbf{n}=\mathbf{1 0})$ & $\mathbf{p}$ \\
\hline Age (years) & $24.30 \pm 5.81$ & $23.30 \pm 4.42$ & $26.40 \pm 4.48$ & 0.373 \\
Height $(\mathbf{c m})$ & $180.00 \pm 4.74$ & $179.35 \pm 7.58$ & $177.40 \pm 6.43$ & 0.640 \\
Body mass $(\mathbf{k g})$ & $80.79 \pm 14.25$ & $72.06 \pm 10.37$ & $80.20 \pm 8.55$ & 0.175 \\
$\Sigma \mathbf{8 S T}(\mathbf{m m})$ & $163.56 \pm 73.08$ & $110.93 \pm 37.97$ & $116.35 \pm 42.75$ & 0.071 \\
\% Fat mass & $22.44 \pm 6.47$ & $17.02 \pm 5.05$ & $17.77 \pm 5.16$ & 0.082 \\
Lean body mass $(\mathbf{k g})$ & $61.99 \pm 6.67$ & $59.46 \pm 6.74$ & $65.71 \pm 5.68$ & 0.107 \\
\hline
\end{tabular}

Values are mean \pm SD. $\%$, percent; $\Sigma 8 S T$, sum of eight-site skinfold thickness; significant difference between groups: $\dagger P<0.05$.

All subjects were carefully informed about the potential risks and discomfort involved in the project and signed a written consent form before their participation in the study. This investigation was approved by the Ethics Committee of Federal University of Rio Grande do Sul (UFRGS) (n2007680).

Subjects were instructed to maintain their food habits and not to drink alcohol or caffeine $12 \mathrm{~h}$ before the evaluation in each part of the study. In relation to physical activities, subjects were asked to avoid strenuous effort at least $24 \mathrm{~h}$ before each evaluation. All groups were oriented to maintain their daily habits and exercise routine during the experimental period.

\section{Procedure}

Subjects attended the test center on five different days. The first session was used to measure body composition and interview the subjects regarding their medical history and physical activity; sessions two and three were used to familiarize the subjects with the exercise execution (bench press and leg press exercises); sessions four and five were used to perform the 1 $\mathrm{RM}$ test and re-test in both exercises. The interval between the first and second session was 1 day, and ranged between 2 and 4 days from others interval sessions. All tests were always made at the same period of the day for each subject.

\section{Body composition}

Body mass and height were measured using an analog scale and a stadiometer (Filizola ${ }^{\mathrm{TM}}$, São Paulo, Brazil). Body composition was assessed using the skinfold technique. Body density was estimated using a four-site skinfold equation based on subscapular, triceps, suprailiac and hamstrings skinfold thickness for men from the South of Brazil, aged 18-65years old (PETROSKI, 1995). To estimate the percentage body fat the Siri equation (HEYWARD e STOLARCZYK, 1996) was used. Skinfold thickness was obtained from the chest, midaxillary, subscapular, suprailiac, abdomen, triceps, thigh and hamstrings.

\section{Familiarization}

Two sessions were necessary to familiarize subjects with the exercise techniques. Each session began with a warm-up (5 min on the cycle ergometer and callisthenic exercises), and stretching. Following this, the bench press and leg press $45^{\circ}$ (World Sculptor equipment, Porto Alegre, Brazil) exercises were performed, in three sets of 12 repetitions in each exercise, with 
intercalated sets and 3 to 5 min rest intervals. The load used in the first set was based on the body mass coefficient (45 and $130 \%$ of body weight of subjects in the bench press and leg press exercises, respectively) proposed by BAECHLE e Groves (2000), while in the remaining sets the loads were adjusted ( $\pm 10 \%$ ) according to a perceived exertion (RPE Borg scale; BORG, 1998) of between RPE 13 and 15 ( $45-55 \% 1$ -

$\mathrm{RM})$ were matched. At the end of each session, the subjects cooled down. The technique and range of the motion determined for each exercise were based on the recommendations proposed for Ratamess et al. (2009).

\section{Strength testing}

Maximal strength in the bench press and leg press $45^{\circ}$ exercises was assessed, in random order, using the one-repetition maximum test and re-test (1-RM1 and 1-RM2, respectively). The tests were performed after a warm up and stretch period (as in the familiarization phase - only one set of 12 repetitions each exercise). Each subject's maximal load was determined in a maximum of five trials. A 3 to 5 -min rest was allowed between trials.
In the 1-RM1 test, the reference for the load used in the first trial was the values considered by the subjects to be their 1-RM value. Starting from this load, subjects were asked to perform the maximum possible number of repetitions. After each trial, the load was adjusted in accordance with coefficients specific to the number of repetitions performed (LOMBARDI, 1989). In the 1-RM2 evaluation test, the initial load corresponded to $95 \%$ of the total load in the 1 $\mathrm{RM} 1$ test, while the remaining procedures were similar to the first evaluation.

\section{Statistical analysis}

The data are shown with mean and standard deviation (SD). The Lilliefors K-S test was used for normality and the Levene test for homogeneity between groups. The association between the 1RM1 and 1-RM2 tests was made with the intraclass coefficient correlation. Two-way ANOVA was used to compare results between tests and groups. The level of statistical significance was set at $p \leq 0.05$. All the tests were carried out using the SPSS for Windows 11.0 software (SPSS Inc., Chicago, IL).

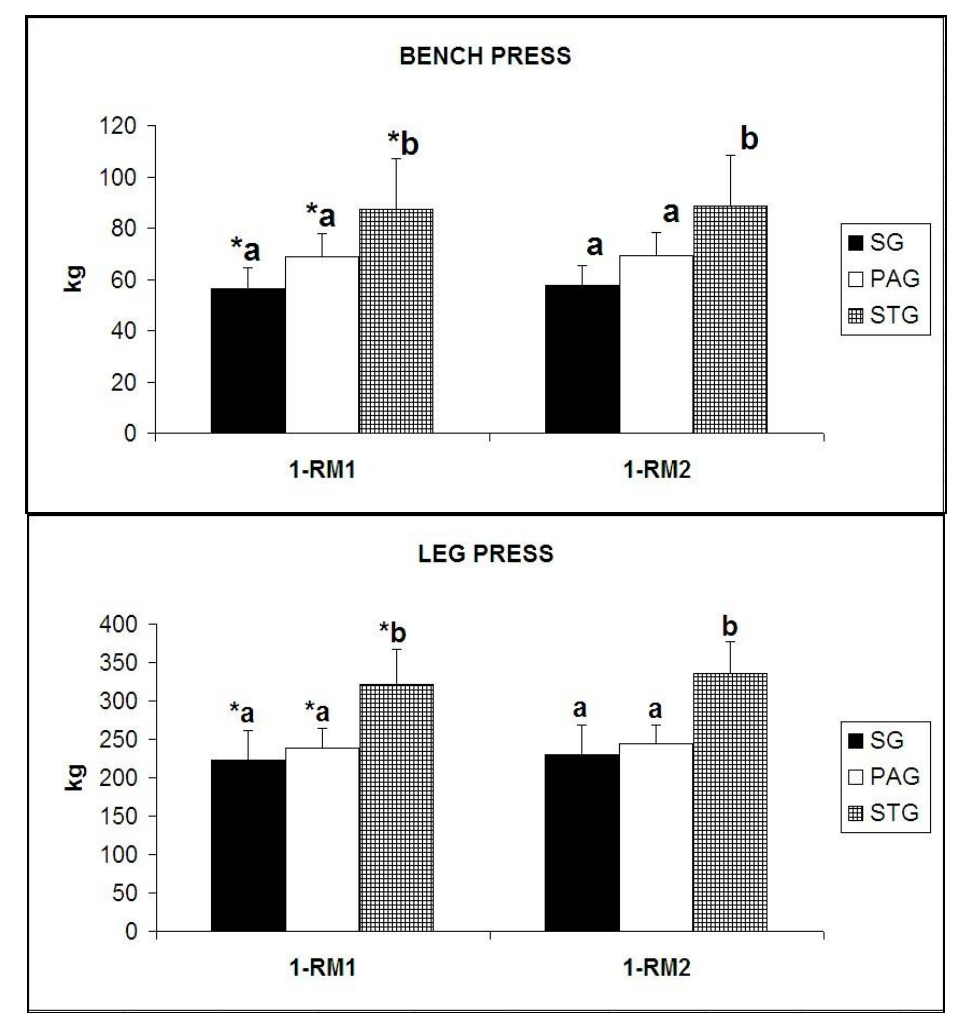

One maximum repetition test and retest values (1-RM1 and 1-RM2) in experimental groups: sedentary ( $S G, n=10)$, physical active (PAG, $n=10$ ) and strength-trained (STG, $n=10$ ).

* indicate significant difference $(p<0.05)$ between $1-R M 1$ and $1-R M 2$ tests. Different letters indicate significant difference $(p<0.05)$ between groups.

Figure 1. Comparison between 1-RM1 and 1-RM2 tests in sedentary, physical active and strength-trained groups for bench press and leg press exercises. 


\section{Results}

Figure 1 shows the results of strength testing for all groups and exercises. STG attained higher values compared to $S G$ and PAG in all tests and exercises $(p<0.05)$. The $1-\mathrm{RM} 2$ tests were superior to 1-RM1 tests in all groups and exercises. The percent variation of the means

\section{BENCH PRESS - sedentary group}

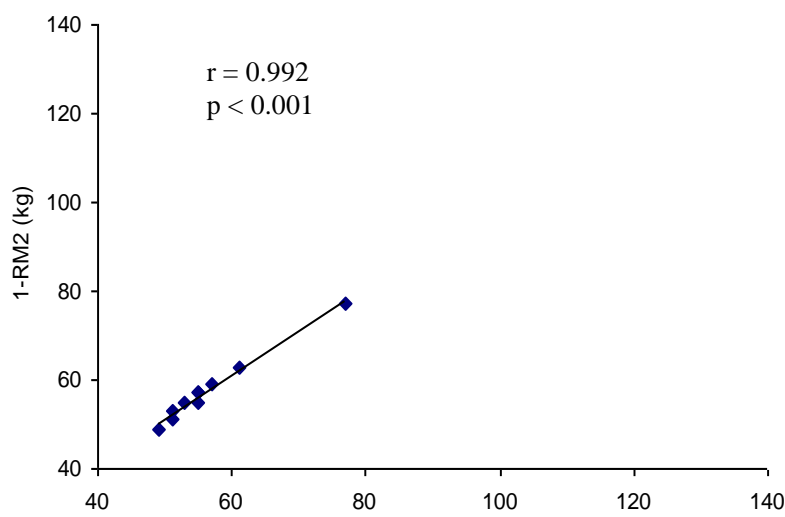

BENCH PRESS - physical active group

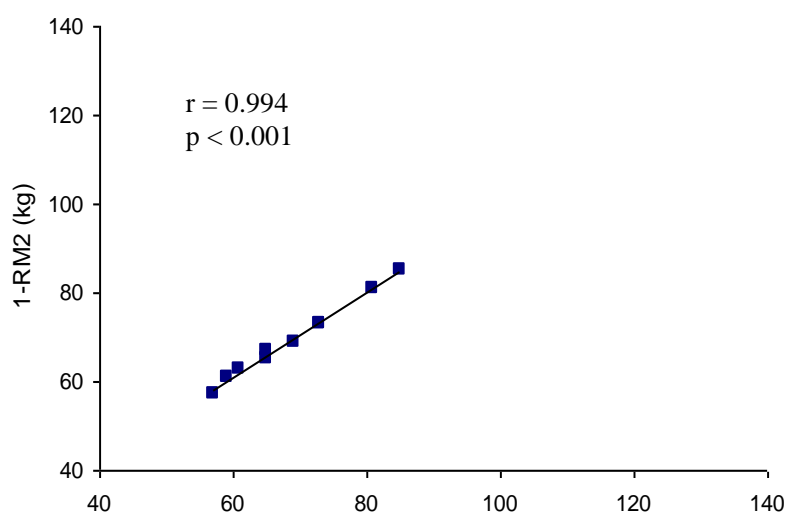

BENCH PRESS - strength trained group

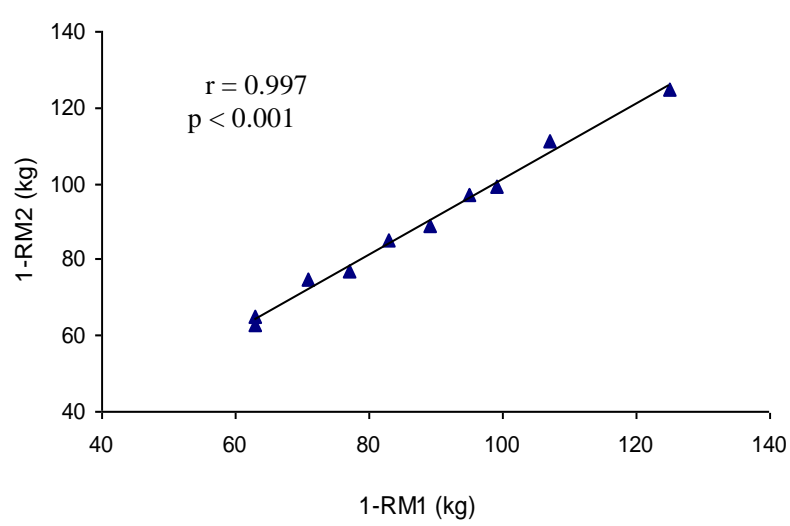

$(\triangle \%)$ between the 1-RM1 and 1-RM2 tests was $2.13 \%$ (0 to $3.77 \%$ ), $0.87 \%$ (0 to $3.39 \%$ ) and $1.61 \%$ ( 0 to $5.63 \%$ ) in the bench press exercise, and $3.15 \%$ (-5.56 to $22.50 \%), 2.31$ (0 to $9.52 \%$ ) and $4.63(-2.94$ a $15.38 \%)$ in the leg press exercise, for SG, PAG and STG groups, respectively.

\section{LEG PRESS - sedentary group}

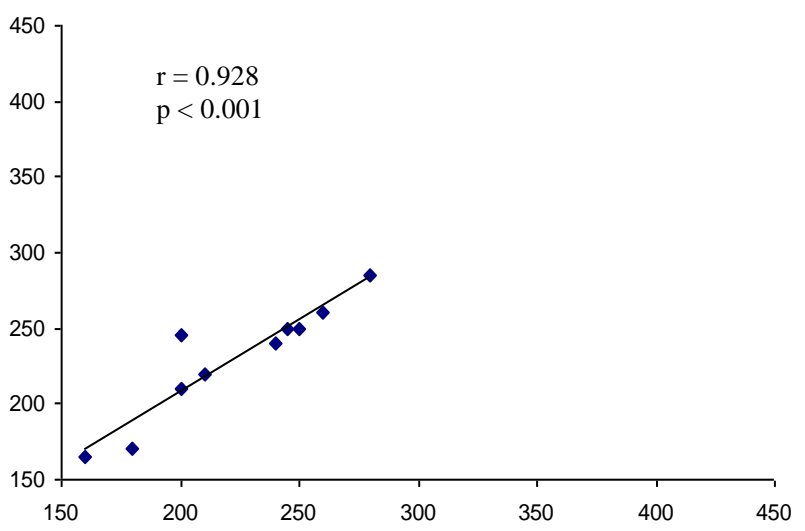

\section{LEG PRESS - physical active group}

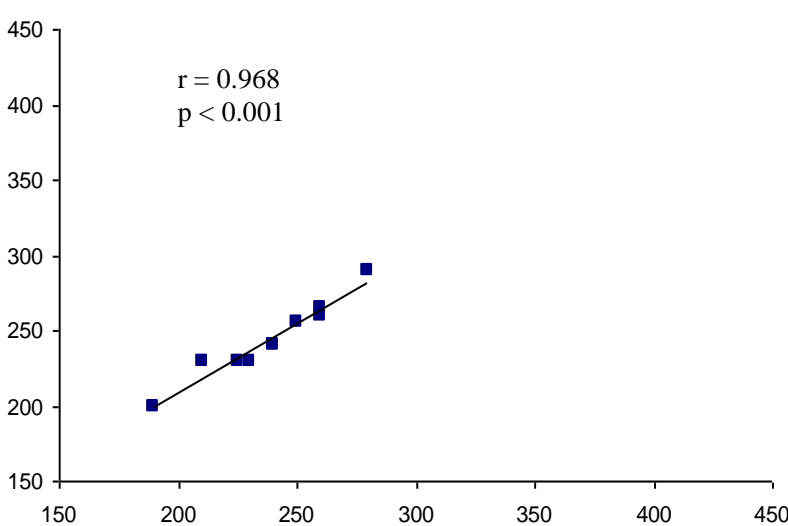

LEG PRESS - strength trained group

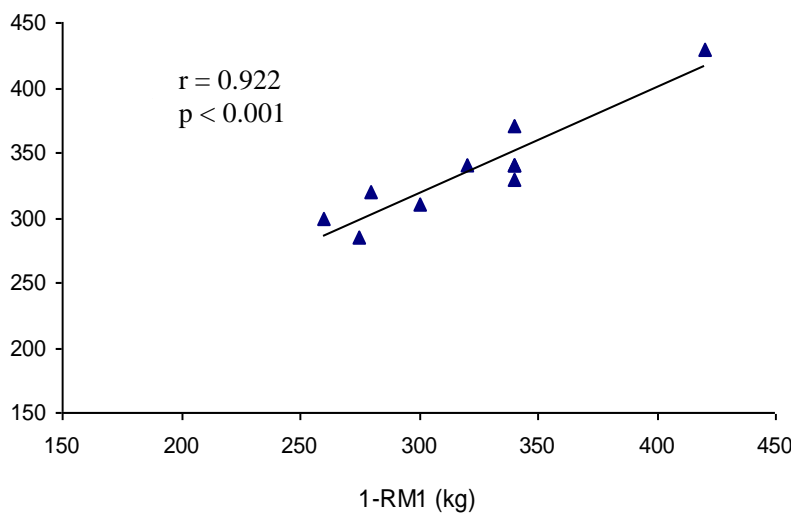

Figure 2. Intraclass correlation coefficients $(r)$ between 1-RM1 e 1-RM2 (kg) tests in sedentary, physical active and strength-trained groups for bench press and leg press exercises. 
Figure 2 shows the intraclass coefficient correlation results between the 1-RM1 and 1-RM2 tests. Correlation variation ranged, according to group and exercise, between 0.922 and 0.997 ( $p<$ 0.001 for all correlations).

\section{Discussion}

The results of our study indicate a high correlation $(r>0.92 ; p<0.001)$ between the $1-R M$ test and retest values in both exercises and groups. However, significant differences $(p<0.05)$ were found between the means in all comparisons between 1-RM1 and 1-RM2 for the experimental groups. These results are in agreement with the study conducted by McCurdy et al. (2004) which compared trained and untrained subjects, and reported correlations higher than 0.97 with significant differences between the 1-RM test and retest, in all subjects, independent of gender. However, in this study the subjects in both groups were unfamiliar with the exercise used in the evaluation (unilateral squat).

For this reason, in order to approximate 1-RM values to the real maximum strength value, the importance of the subjects' familiarity with the exercises to be evaluated has been pointed out (ATKINSON e NEVILL, 1998; PEREIRA e GOMES, 2003; LEVINGER et al., 2009). It is believed that based on a suitable familiarization process, the learning effects can be minimized and the maximum voluntary strength value can be reached. The learning effects are thought to include the neural adaptations that occur as result of the initial ST or strength evaluation sessions, such as the reduction in antagonist muscle coactivation, the disinhibition of the Golgi tendon organs in the agonist musculature, enhanced intra and inter-muscular coordination and the increase in motor unit recruitment and electrical impulse firing frequency (PLOUTZ-SNYDER e GIAMIS, 2001). These differences between the maximum voluntary strength and the maximum absolute capacity of the neuromuscular system is known as strength deficit, which is greater in untrained subjects $(30-45 \%)$, when compared to trained subjects (5\%; CRONIN e HENDERSON, 2004).

In the present study, although the mean variations found between the 1-RM tests were statistically different $(p<0.05)$ in all comparisons made, the magnitude was low, ranging between 0.87 and $2.13 \%$ in the bench press and 2.31 and $4.63 \%$ in the leg press, in the different groups. Levinger et al. (2009) evaluated untrained men and women in seven different exercises, and found similar variations, ranging from 2.2 to $6.5 \%$ between the 1-RM test and retest, in the exercises. Possibly, the familiarization process adopted in the present study contributed towards these low variations. Hakkinen (1985) reports that rapid increases in maximum strength can be achieved in the first weeks of training in subjects with low levels of physical fitness $(6.8-10 \%$ in the first week, $9.9-13.8 \%$ in the second week and 13.6 - 16.8 in three weeks). The protocol chosen during the present study (familiarization, warm up, the attempts to surpass the load during the 1-RM test) could represent sufficient stimulus to improve maximum strength, principally in subjects with low strength levels, decreasing the strength deficit between the first and second 1-RM evaluation, thus representing high reliability values and low variation 1-RM values.

Related to trained subjects, it is worth mentioning the study from Dias et al. (2005), in which four 1-RM test were performed in three exercises. In that study high intraclass correlation values $(r>0.96)$ and low percentage variations (2.4 to $5.4 \%$ ) were found between the first and fourth attempts in different exercises. In addition, in order to stabilize the 1-RM, at least two sessions were found to be necessary in the biceps curl, while three were needed in the bench press and squats. In relation to these findings, Dias et al. (2005) believe that explanations (neuromuscular factors) could account for to these differences. Although the sample in our study was randomly evaluated, other factors may also contribute towards this understanding, such as the motivation of the subjects (RYDWIK et al., 2007), physical predisposition on different days and environmental conditions, among others (MORROW et al., 2003).

With regard the behavior patterns in the different exercises, in the present study, higher correlation values were in the bench press $(r \cong$

0.99 vs. 0.92). Cronin e Henderson (2004) suggest the size of the muscle groups involved or the complexity of the execution of the exercises may account for such differences. In their study, the bench press (using equipment) presented lower strength increases than the squat exercise (using equipment) (13.6\% vs. 16.8\%, respectively) in successive tests. The authors suggest that the small muscle mass actived in the bench press could lead to a lower strength deficit, while the 
greater complexity of the movement and the higher loads used in the squat exercise could led greater inhibition of the neuromuscular system in that task. Nevertheless, while another study (TAGESSON e KVIST, 2007) also associates lower correlations in more complex exercises, this is not applicable in the present study, since the bench press was performed with free weights, while guided equipment was used for the leg press, which would suggest that the volume of muscle mass involved may have more influence in the responses of reliability.

There is an important limitation in the present study: the 1-RM of only two exercises were analyzed, the bench press and the leg press in young men. Thus, the results found cannot be generalized to other exercises and populations.

\section{Conclusion}

To conclude, high correlations were found in the bench press and leg press exercises, independent of the evaluated experimental group, with the 1-RM2 tests were superior to 1-RM1 tests in all groups and exercises, suggesting that familiarization to strength exercises and 1-RM test, done before the definitive test, increases the reliability of the results of the 1-RM test.

Based on the results of this study, where a high degree of accuracy is required for the maximum strength values, we suggest as practical applications that at least two familiarization sessions and two 1-RM evaluation tests should be carried out to ensure high reliability values. Hence, both in scientific research and for the purposes of personal training, the reproducibility of the 1-RM tests is an extremely important factor when evaluating the real efficiency of an ST protocol.

Further research is needed to determine if similar levels of reliability would be found in other subjects, such as highly trained athletes, women, and adolescents.

\section{Referências}

ATKINSON, G.; NEVILL, A. M. Statistical methods for assessing measurement error (reliability) in variables relevant to sports medicine. Sports

Medicine, Auckland, N.Z., v.26, n.4, p.217-238, 1998.

BAECHLE, T. R.; GROVES, B. R. Treinamento de Força: Passos para o sucesso. Porto Alegre: Artmed, 2000.
BORG, G. Borg's perceived exertion and pain scales. Champaign: Human Kinetcs, 1998.

BROWN, L. E.; WEIR, J. P. ASEP procedures recommendation I: Accurate assessment of muscular strength and power. Journal of

Exercise Physiology online, Duluth, E.U.A., v.4, n.3, p.1-21, 2001. Disponível em:

$<$ http://faculty.css.edu/tboone2/asep/Brown2.pdf>. Acesso em 10 abr. 2011.

CRONIN, J. B.; HENDERSON, M. E. Maximal strength and power assessment in novice weight trainers. Journal of Strength and Conditioning Research, Lincoln, E.U.A., v.18, n.1; p.48-52, 2004.

DIAS, R. M. R.; CYRINO, E. S.; SALVADOR, E. $P$.; et al. Influência do processo de familiarização para avaliação da força muscular em testes de 1RM. Revista Brasileira de Medicina do Esporte, São Paulo, BR., v.11, n.1; p.34-42. 2005.

Disponível em: <http://dx.doi.org/10.1590/S151786922005000100004>. Acesso em: 09 out. 2011.

GURJÃO, A. L. D.; CYRINO, E. S.; SOARES CALDEIRA, L. F.; et al. Variação da força muscular em testes repetitivos de 1-RM em crianças pré-púberes. Revista Brasileira de Medicina do Esporte, São Paulo, BR., v.11, n.6, p.319-324. 2005. Disponível em :

$<$ http://dx.doi.org/10.1590/S151786922005000600003>. Acesso em: 09 out. 2011.

HAKKINEN, K. Research overview: Factors influencing trainability of muscular strength during short term and prolonged training. National

Strength and Conditioning Association, Colorado Springs, E.U.A., v.7, n.2, p.32-37, 1985.

HEYWARD, V. H.; STOLARCZYK, L. M. Applied body composition assessment. USA: Human Kinetics, 1996.

HUNTER, G. R.; WETZSTEIN, C. J.; MCLAFFERTY, C. L.; et al. High-resistance versus variable resistance training in older adults. Medicine and Science in Sports and Exercise, Indianapolis, E.U.A., v.33, n.10, p.1759-1764, 2001.

KRAEMER, W. J.; NINDL, B. C.; RATAMESS, N. A.; et al. Changes in muscle hypertrophy in women with periodized resistance training. Medicine and Science in Sports and Exercise, Indianapolis, E.U.A., v.36, n.4, p.697-708. 2004.

LEVINGER, I.; GOODMAN, C.; HARE, D. L.; et al. The reliability of the $1 \mathrm{RM}$ strength test for untrained middle-aged individuals. Journal of Science and Medicine in Sport, Sydney, AUS., v.12, n.2, p.310-316, 2009. Disponível em : 
<http://dx.doi.org/10.1016/j.jsams.2007.10.007>. Acesso em: 09 out. 2011.

LOMBARDI, V. P. Beginning weight training: the safe and effective way. Dubuque, 1989.

MCCURDY, K.; LANGFORD, G. A.; CLINE, A. L.; et al. The reliability of 1 and $3 \mathrm{RM}$ tests of unilateral strength in trained and untrained men and women. Journal of Sports Science and Medicine, Bursa, TR., v.3, n.3, p.190-196, 2004. Disponível em:

<http://www.jssm.org/vol3/n3/10/v3n3-10pdf.pdf>. Acesso em 10 abr. 2011.

MORROW, J. R.; JACKSON, A. W.; DISCH, J. G.; MOOD, D. P. Medida e Avaliação do Desempenho Humano. Porto Alegre: Artmed, 2003.

PEREIRA, M. I. R.; GOMES, P. S. C. Testes de força e resistência muscular: confiabilidade e predição de uma repetição máxima - Revisão e novas evidências. Revista Brasileira de

Medicina do Esporte, São Paulo, BR., v.9, n.5, p.325-335. 2003. Disponível em:

$<$ http://dx.doi.org/10.1590/S151786922003000500007>. Acesso em: 09 out. 2011.

PETROSKI, E. L. Desenvolvimento e Validação de Equações Generalizadas para Predição da Densidade Corporal. Tese de Doutorado. Universidade Federal de Santa Maria, Santa Maria, 1995. Disponível em:

<http://www.nucidh.ufsc.br/teses/tese edio.pdf>. Acesso em: 10 abr. 2011.

PLOUTZ-SNYDER, L. L.; GIAMIS, E. L. Orientation and familiarization to $1 \mathrm{RM}$ strength testing in old and young women. Journal of Strength and Conditioning Research, Lincoln, E.U.A., v.15, n.4, p.519-523. 2001.

RATAMESS, N. A.; ALVAR, B. A.; EVETOCH, T. $\mathrm{K}$; ; et al. Progression models in resistance training for healthy adults. Medicine \& Science in Sports \& Exercise, Indianapolis, E.U.A., v.41, n.3, p.687708, 2009. Disponível em:

$<$ http://dx.doi.org/10.1249/MSS.0b013e318191567 0) $>$. Acesso em: 09 out. 2011.

RITTI-DIAS, R. M.; AVELAR, A.; SALVADOR, E. $P$.; et al. Influence of previous experience on resistance training on reliability of one repetition maximum test. Journal of Strength and Conditioning Research, Lincoln, E.U.A., v.25, n.5, p.1418-1422, 2011.

RYDWIK, E.; KARLSSON, C.; FRÄNDLIN, K.; AKNER, G. Muscle strength testing with one repetition maximum in the arm/shoulder for people aged 75+ - Test-retest reliability. Clinical

Rehabilitation, Londres, G.B., v.21, n.3; p.258-
265. 2007. Disponível em: <http://wwwusers.york.ac.uk/ mb55/msc/clinimet/exam/rydwik 2007.pdf >. Acesso em: 10 abr. 2011.

TAGESSON, S. K. B.; KVIST, J. Intra- and interrater reliability of the establishment of one repetition maximum on squat and seated knee extension. Journal of Strength and Conditioning Research, Lincoln, E.U.A., v.21, n.3, p.801-807, 2007.

TAN, B. Manipulating resistance training program variables to optimize maximum strength in men: a review. Journal of Strength and Conditioning Research, Lincoln, E.U.A., v.13, n.3, p.289-304, 1999.

\author{
Endereço: \\ Carlos Leandro Tiggemann \\ Lapex, Escola de Educação Física, UFRGS. \\ Rua Felizardo, 750 Jardim Botânico \\ Porto Alegre RS Brasil \\ 90690-200 \\ Phone: $+55(51) 3308.5820$ \\ Fax: $+55(51) 3308.5842$ \\ e-mail: cltiggemann@yahoo.com.br
}

Recebido em: 16 de abril de 2011.

Aceito em: 07 de setembro de 2011.

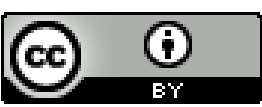

Motriz. Revista de Educação Física. UNESP, Rio Claro, SP, Brasil - elSSN: 1980-6574 - está licenciada sob Creative Commons - Atribuição 3.0 